\title{
UWARUNKOWANIA MISJI BIBLIOTEK W SPOLECZEŃSTWIE WIEDZY I INFORMACJI. WIZERUNEK I TOŻSAMOŚĆ
}

\begin{abstract}
The article concerns the contemporary librarianship and the place of libraries in the information society. Rapid growth of information is conducive to the development of libraries, defining their mission and building their image in the modern world. Author points out several areas that affect the internal image of the library. These are: process management, communication and exchange of information, internal relations, the level of motivation of the staff, image management style and management system, the atmosphere in the workplace, conditions for staff development, integration activities, interpersonal communication, working conditions, an identification system for employees, good external image. It also describes the competences of modern librarians: creativity, ability to cooperate, the use of information technology, communication skills and efficiency in planning. Modern library is a place for meetings and cultural activity of the environment, for which it is assigned.
\end{abstract}

Słowa kluczowe: społeczeństwo informacyjne, bibliotekoznawstwo, misja bibliotek, wizerunek i tożsamość bibliotek.

\section{Otwartość}

Współczesne biblioteki i bibliotekarze są coraz lepiej postrzegani, zauważani w mediach, doceniani za kreowanie potencjału kulturowego, nagradzani w konkursach edukacyjnych, nazywani protagonistami nowoczesnego społeczeństwa i animatorami postaw obywatelskich. Życie bibliotek i bibliotekarzy wzbogaciło się o działania uzupełniające i urozmaicające egzystencję, bowiem, parafrazując Susan Sontag, aktywność społeczna polega na prowadzeniu życia, w którym się myśli, i myśleniu o życiu, które się prowadzi ${ }^{1}$. Autorefleksja $\mathrm{w}$ profesji bibliotekarskiej polega na intensywnym doznaniu aktywności i zmienności otaczającego świata. Istotna jest także samoświadomość bibliotekarzy, iż reprezentują realne środowiska, w których pracują (naukowe, inteligenckie, robotnicze, chłopskie, spauperyzowane, wykluczone, odmienne

\footnotetext{
${ }^{1}$ J. Cott, Myśl to forma odczuwania, Susan Sontag w rozmowie z..., Kraków 2014, s. 7.
} 
kulturowo i inne ${ }^{2}$ ), a nie samych siebie. Biblioteki jako instytucje oświatowe stają się kanałem przekazu kultury, a jako instytucje kulturalne poszerzają i redefiniują ramy instytucjonalne edukacji. W związku z tym kulturalnooświatowy charakter działalności bibliotekarskiej w sposób naturalny włącza bibliotekarzy w kształcenie ustawiczne i, szczególnie ważna w środowiskach lokalnych, ideę na rzecz przeciwdziałania wykluczeniom ${ }^{3}$. Oczywistym jest, że biblioteka to element pejzażu miejsca i epoki, w której istnieje, choć dawniej podkreślano to mocniej opisując podróże i odległe miasta ${ }^{4}$. Filozofia nowożytnej otwartej biblioteki zaczęła kiełkować wraz z pojawieniem się środowisk naukowych, które narzucały opinii publicznej własne kryteria wartościowania poczynań ludzkich. Prywatne zbiory biblioteczne od dawna traktowane były jako instrumenty badań naukowych, ale w jeszcze większym stopniu jako świadectwa wysokiej pozycji społecznej ich posiadaczy. Krzysztof Pomian pisał, iż dawniej „rzadki lub zgoła unikalny rękopis był dla uczonego tekstem, który należało opublikować, by uratować go przed niebezpieczeństwem zniszczenia, a zarazem wzbogacić dzięki niemu wiedzę o rzeczach minionych; posiadacz tego rękopisu czerpał natomiast zadowolenie z faktu, iż nie był on nigdy ogłoszony, ponieważ wskazywało to na wartość biblioteki, a tym samym na rangę tego, kto ją skompletował, na jego bogactwo lub miejsce w społecznej hierarchii. Jeszcze w 1714 r. odmówiono Leibnizowi wypożyczenia jakichś niepublikowanych kodeksów z Biblioteki Cesarskiej w Wiedniu, ponieważ mógł je skopiować i wydać, działając w ten sposób na szkodę owej biblioteki"

Idea otwartego dostępu do księgozbiorów była stopniowo wprowadzana w życie za sprawą XVII wiecznych intelektualistów, którzy - jak flamandzki erudyta Justus Lipius - nawoływali do otwierania książnic dla uczonych, stawiając za wzór Muzeum Aleksandryjskie ${ }^{6}$. Inni, jak Godefridus Henschenius i Daniel Papebroch, znani w Europie bollandyści, pisali listy do kanclerza Pierre'a Sugiera, aby ten zechciał wypożyczyć na krótko jeden z jego rękopisów do biblioteki Collège de Clermont celem przepisania. W uzasadnieniu prośby

\footnotetext{
${ }^{2}$ Autor ma na myśli niestandardowe działania, jak te, zawarte w projekcie realizowanym przez Fundację Rozwoju Społeczeństwa Informacyjnego „Biblioteka miejscem spotkań wielu kultur" - finansowanym z funduszy pochodzących z Islandii, Liechtensteinu i Norwegii.

${ }^{3}$ Zob. na ten temat: J. Ladorucki, Mate ojczyzny - lokalne biblioteki - nowe oblicza bibliotekarskiej profesji, [w:] Bibliologia i informatologia, red. D. Kuźmina. Warszawa 2011, s. 89-99.

${ }^{4}$ Jako przykład $\mathrm{z}$ ostatnich lektur autora niech stanowią paryskie wspomnienia Tadeusza Peipera: „Miasto tętniące wrzącą wieczną pracą; miasto najpiękniejszych starych budowli, najwspanialszych starych budowli, najwspanialszych muzeów, bibliotek, kościołów, sal uniwersyteckich i teatralnych [...] Paryż! [...] Olbrzymie gmachy, w które myśl ludzka włożyła wszystkie siły piękna i bogactwa [...]. Miejsce spotkania prawd i czynów. Ruch, blask, szum! Życie!” Cytat za: T. Peiper, Ma lat 22, Kraków1936, s. 325-326, 361.

${ }^{5}$ K. Pomian, Przeszlość jako przedmiot wiedzy, Warszawa 2010, s. 134.

${ }^{6}$ Ibidem, s. 133.
} 
przytaczali, iż podobnej łaski użyczyli im wcześniej papież, królowa Krystyna Szwedzka, liczni kardynałowie i inne znakomitości dworu francuskiego, jak spowiednik Ludwika XIV, ojciec François Annat ${ }^{7}$. Wprowadzenie powszechnego dostępu do księgozbiorów równoznaczne jest uznaniu, że wszyscy ludzie są równi i dostrzeganiu nowoczesnej misyjnej idei biblioteki dostępnej dla wszystkich. Od dawna też wskazywano na misję zawodu i szczególne powołanie ludzi pracujących z księgozbiorami. Na ziemiach polskich widać to w czasach tworzenia Biblioteki Ossolińskich i w słynnym traktacie o Obowiazkach bibliotekarza z 1829 roku. Stanisław Dunin-Borkowski pisał: „Nie ma zapominać Bibliotekarz, że księgozbiór, którym zawiaduje, nie jest tylko dla jego użytku i zabawy, ale dla publiczności i potomności wystawiony. Każda biblioteka powinna zawierać zbiór wszystkich materiałów do historii nauk przyszłym wiekom służyć mogących. Niech pomni Bibliotekarz, że ta nauka, którą on przedkłada, albo dziś jest w modzie, wkrótce może obojętną się stanie [...] Sława biblioteki powinna być sławą jego osobistą, na jej ustalenie, i coraz większe rozszerzenie powinien poświęcać wszystkie swoje czyny, wszystkie niewczasy, wszystkie trudy i nieprzyjemności, wszystkie zgoła całego życia prace, a tak tylko stanie się godnym swego szlachetnego powołania"8.

Styl działania współczesnych bibliotek umyka dawnym standardom i budzi uśpiony potencjał. Warto podkreślać, iż biblioteki jako miejsca nie służą wszechobecnej sprzedaży, ale zachęcają do działania; ich otwartość to prowokacja zachęcająca do myślenia, do partycypacji. Każda biblioteka może się rozwijać jedynie przez adaptację i tworzenie relacji z otoczeniem, rozumianym jako zbiór zjawisk, procesów i instytucji kształtujących stosunki wymienności. Dynamika otoczenia współczesnej biblioteki, charakteryzująca się złożonością narzuca określone sposoby działania, stymuluje zmiany i rozwój.

\section{Natłok informacji}

Współczesne realia, pobudzane nieustannym przepływem informacji, uległy tak licznym przekształceniom, że wywołują naturalne refleksje. Żyjemy bowiem w świecie, w którym wszystkiego przybywa. Coraz więcej jest ludzi, sprzętów audiowizualnych, publikacji (tych papierowych i elektronicznych); modyfikuje się bezustannie techniki i narzędzia, przybywa pól myślenia, mnoży się dobro, ale prawdopodobnie przybywa też zła, więcej jest biedy i bogactwa. Świat nie kurczy się, jak sugerowała modna dawniej metafora globalnej wioski, lecz rozrasta i wchłania w siebie wszystko. Coraz więcej rzeczy wspólistnieje ze sobą, coraz więcej zjawisk i wydarzeń zachodzi w świecie równocześnie. Kultura ludzka mieści w sobie różne formy, które wzbogacają się nawzajem i uzupełniają. Powiększa się tak zwany łańcuch medialny, który

\footnotetext{
${ }^{7}$ Ibidem, s. 135.

${ }^{8}$ S. Dunin-Borkowski, O obowiązkach bibliotekarza, Lwów 1829, s. 36, 38.
} 
stawia szczególne wyzwania specjalistom informacji naukowej, którzy stają się kimś więcej niż bibliotekarzami nowoczesnej kultury i nauki. Współczesne kierunki rozwoju mediów, w dobie ich konwergencji, są trudne do przewidzenia. Prasa drukarska zapoczątkowała budowę nowoczesnego świata, a komputer połączony z Internetem powołał do życia hybrydowego nadawcę i odbiorcę, podmiot i przedmiot, przyczynę i efekt procesów komunikacyjnych. Media osadzają się coraz głębiej w naszej rzeczywistości i nadają nowy sens ludzkim poczynaniom ${ }^{9}$. Książka papierowa przestała być tak uprzywilejowanym środkiem komunikowania jak dawniej. Trwają dyskusje nad końcem epoki Gutenberga. Pada wiele, często naiwnych, argumentów z różnych stron, ale rewolucja informacyjna jest faktem. Wydaje się, że niekończące się dyskusje futurologiczne nad tym, czy komputery są wrogami książek, czy epoka analogowa umiera na naszych oczach, niewiele wnoszą nowego do dyskursów humanistycznych. Koniec papierowego świata, radia, kina, ogłaszano wielokrotnie. Wydaje się, że nowe media są takim samym zagrożeniem dla tradycyjnej książki, jak winda dla schodów. Przecież wciąż budujemy obok siebie - jedne i drugie.

Realnym efektem tych zjawisk jest ustawiczny przyrost informacji. Rozrasta się otoczenie informacyjne współczesnego człowieka. Dawniej liczba informacji i dokumentów, które gromadzono w ciągu życia mieściła się w jednej dłoni (w uproszczeniu: akt urodzenia, ślubu, dokumenty kościelne, medyczne, sądowe, akt zgonu - to właściwie wszystko, by spokojnie żyć). Współcześnie rozrastające się instytucje społeczne i administracyjne, produkują dokumenty w tysiącach egzemplarzy i oczekują współpracy, reakcji, odpowiedzi. Przez uchylone drzwi, do naszych domów wślizgują się reklamy, oferty, ulotki. Wszystko to, to mniej lub bardziej ważne informacje, które w coraz większym stopniu dominują otoczenie, a człowiek ponowoczesny nie potrafi żyć bez dobrych i złych wiadomości ${ }^{10}$.

Niepostrzeżenie wkroczyliśmy w wiek informacji. Pojawiło się społeczeństwo informacyjne jako trzecie stadium cywilizacyjne (po rolniczym i przemysłowym). Era informacji opiera się o Internet, który przyniósł znaczące korzyści: dał wiedzę, szanse ekonomiczne oraz rozwój kapitału społecznego. Nieuchronnie pojawiły się także zagrożenia (uzależnienie od Internetu, bezrobocie technologiczne, potrzeba re-kwalifikacji). Dają się zauważyć społeczne „nierówności cyfrowe”, ataki hakerów, crackerów, lamerów, script kiddie, łamiące zabezpieczenia programowe dla zarobku i zniszczenia systemu, WikiLeaks, e-wojny i wirusy. Obok tego stwierdzono analfabetyzm informacyjny, jako

\footnotetext{
${ }^{9}$ Zob. P. Levinson, Miękkie ostrze, czyli historia i przyszłość rewolucji informacyjnej, Warszawa 2006.

${ }^{10} \mathrm{Czym}$ jest aktualna i użyteczna informacja, pokazuje obrazowa anegdota. Informacja o aktualnych wynikach wieczornego losowania Lotto jest bezcenna tu i teraz, jednak następnego dnia te same dane będą już tylko mało znaczącą statystyką w zestawie wyników z ostatniego tygodnia.
} 
sytuację, w której zmuszeni jesteśmy uczyć się od maszyn, bowiem nie potrafimy posługiwać się informacją, przetwarzać jej, prezentować i dystrybuować; nie odróżniamy danych od informacji a informacji od wiedzy. „Rzecz w tym, że nowe media nie pytają o zgodę"11, jak stwierdził Jason Epstein, a rozwój sektora informacji w gospodarce zaczął wytwarzać nowe, nieznane wcześniej zjawiska, na przykład:

- $\quad$ produkcję i przetwarzanie informacji (technologie hardware i software);

- $\quad$ dystrybucje informacji (widoczne w telekomunikacji i telewizji cyfrowej);

- rozwinął się także segment usługi w zakresie udostępniania informacji, głównie poprzez biblioteki;

- $\quad$ w bibliotekach powstają eksperymentalne przestrzenie kreatywności typu makerspace. Doświadczenie pokazuje iż biblioteka i idea do it yourself świetnie do siebie pasują.

Gwałtowna i radykalna transformacja techniczna, ekonomiczna, systemowa i kulturowa dotyczy całego otoczenia, pośrednio i bezpośrednio. Dla współczesnych społeczeństw informacyjnych towarem jest informacja, traktowana jako szczególne dobro niematerialne, równoważne lub cenniejsze nawet od dóbr materialnych. Towarzyszące rozwojowi społeczeństwa informacyjnego zjawiska przetwarzania informacji i edukacji w zakresie jej dystrybucji i zastosowania, stanowią szansę dla bibliotekarzy jako specjalistów w tym zakresie. Dodatkowo, aspekt kreowania społeczeństwa przez Internet i rozwijające się technologie, daje bibliotekom szanse wykorzystania dostępnego im softwaru, a nawet zarabiania na przetwarzaniu informacji. Szanse rozwojowe społeczeństwa informacyjnego, służą demokracji poprzez wolny dostęp do zasobów informacyjnych i prawo do bycia informowanym oraz informowania wszystkich, niezależnie od sytuacji i miejsca pobytu lub zamieszkania. Bibliotekarstwo jako aktywność zawodowa uległo zasadniczym zróżnicowaniom i coraz trudniej mówić i myśleć o nim jako o jednolitej rodzajowo profesji. Wymaga więc nie tylko naukowej analizy i badań, ale też rozumienia i refleksji ze strony przedstawicieli zawodu. Wiedza o powstającym społeczeństwie informacyjnym staje się pożądanym produktem pierwszej potrzeby, a jej nadawcami powinni być między innymi bibliotekarze, jako interpretatorzy i budowniczy informacji. Także sama biblioteka już dawno przestała być spokojną wyspą na wzburzonym oceanie życia - jak mawiali dawniej ci, którzy nie doceniali pracy bibliotekarzy. Inne są zadania bibliotekarzy gminnych bibliotek publicznych i ich praca na rzecz małych ojczyzn. Inne są zadania bibliotekarzy/specjalistów informacji w dużych i wysoko skomputeryzowanych bibliotekach wyższych uczeni. Silne poczucie misji i zrozumienie wśród bibliotekarzy społecznej wagi zawodu nie idą jednak w parze z działaniami kręgów opiniotwórczych, naukowców i polityków, aby budować wokół książnic przestrzeń społecznej akceptacji i poczucia funkcjonalnej niezbędności tych instytucji w każdym

${ }^{11}$ J. Epstein, Rewolucyjna przyszłość książek, [w:] Ekonomia kultury. Przewodnik Krytyki Politycznej, Warszawa 2010, s. 162. 
środowisku w Polsce ${ }^{12}$. Sami bibliotekarze nie podejmują systemowych działań budujących misję bibliotek i ich najlepszy wizerunek. Rodzi się także pytanie, jak mówić o współczesnych bibliotekach, aby być zrozumianym? Czy językiem ambiwalentnej teorii, która zawsze pozostawia z wątpliwościami część nieprzekonanych do naukowych dyskursów, czy może językiem Umberta Eco, który niejednokrotnie wyrażał bezradność wobec faktu natłoku informacji i trudności ich syntezy? ${ }^{13}$

\section{Wizerunek i tożsamość}

Wizerunek i tożsamość współczesnych bibliotek to elementy, które identyfikują te instytucje w przestrzeni fizycznej i mentalnej ${ }^{14}$. Wizerunek i tożsamość nie jest tym samym, ale ich związek wewnętrzny jest oczywisty, tak samo, jak i wpływ na misję książnic. Obydwa pojęcia mają charakter dynamiczny i powstają w sposób ewolucyjny. Wizerunek tworzy osobowość instytucji (firmy), marek, produktów ${ }^{15}$ : „W przeciwieństwie do wizerunku, który odzwierciedla opinie, tożsamość jest czymś obiektywnym, ponieważ składają się na nią różnego rodzaju elementy, za pomocą których organizacja jest identyfikowana (na przykład znak, barwy firmowe, normy zachowań i inne). Można powiedzieć, że tożsamość to zbiór pewnych określonych bodźców, a wizerunek to sposób, w jaki są one odczytywane"16. Wizerunek, najogólniej mówiąc, to pozytywny obraz instytucji w percepcji jego otoczenia, stworzony na skutek aktywnych i świadomych działan ${ }^{17}$. Józef Szocki podaje, że wizerunek firmy powstaje jako rezultat oddziaływania trzech grup czynników:

- indywidualnych potrzeb, motywacji, sposobów uczenia się i postrzegania rzeczywistości (dotyczą one wewnętrznych procesów mentalnych kreujących wizerunek firmy i stanowią wypadkową takich celów nabywców/ użytkowników, jak: wiek, wykształcenie, zawód, przynależność do określonej grupy społecznej, dochód i temu podobne). Te atrybuty przyczyniają się do powstania między innymi potrzeb i motywacji;

- $\quad$ cech samej firmy (głównie tych, które dostrzegają nabywcy); subiektywne ich postrzeganie to determinanty wizerunku;

\footnotetext{
${ }^{12}$ Por. J. Ladorucki, op. cit.

${ }^{13}$ Chodzi między innymi o dewizę Wittgensteina umieszczoną na obwolucie pierwszego wydania Imienia róży, która świadczy o dwugłosowości Eco i brzmi „O czym nie można teoretyzować, to musimy opowiedzieć".

${ }^{14} \mathrm{Na}$ temat wizerunku bibliotek publicznych prowadzono badania empiryczne. Zob.: Ł. Ostrowski, Wizerunek bibliotek publicznych. Raport z badań, [dostęp: 01.06.2015], https:// wirtualnysegregator.org/repository/PLIKI/DOKUMENTY/RAPORTY/03_wizerunek_bibliotek_ publicznych_raport_PRB.pdf.

${ }^{15}$ B. Rozwadowska, PR. Teoria. Praktyka. Perspektywy, Warszawa 2009, s. 194.

${ }^{16}$ Ibidem.

${ }^{17}$ W. Budzyński, Zarzadzanie wizerunkiem firmy, [w:] Metody badania wizerunku w mediach, red. T. Gackowski, M. Łączyński, Warszawa 2009, s. 80.
} 
- oddziaływania osób trzecich (uwarunkowania kulturowe, społeczne, technologiczne, ekonomiczne i naturalne: wpływ członków rodzin, grup odniesienia, liderów opinii) ${ }^{18}$.

Wizerunek posiada odniesienia wewnętrzne, jak i zewnętrzne, które można jeszcze podzielić na bliższe i dalsze. Otoczenie wewnętrzne biblioteki to nie tylko pracownicy (pion kierowniczy, rada biblioteczna), osoby związane bezpośrednio z funkcjonowaniem instytucji bibliotecznej (nadzór merytoryczny, członkowie kół przyjaciół biblioteki, stowarzyszeń), ale również ich rodziny, bliscy i znajomi.

Do otoczenia zewnętrznego bliższego zaliczyć należy czytelników oraz innych użytkowników wykorzystujących w jakikolwiek sposób zbiory (dobra) zgromadzone w bibliotece (ludzie nauki, sztuki, studenci, animatorzy życia społecznego); także organizacje społeczne, inne instytucje kulturalne, lokalne władze i instytucje finansowe, związki zawodowe oraz lokalną społeczność. Otoczenie zewnętrzne dalsze stanowią tak zwani liderzy opinii (kręgi opiniotwórcze); mogą nimi być dziennikarze, instytucje kultury i nauki (także konkurencyjne biblioteki prywatnych i państwowych szkół wyższych), władze centralne, ugrupowania polityczne, media w szerokim rozumieniu.

Zazwyczaj wymienia się trzy typy wizerunku: wizerunek zwykły, pożądany oraz lustrzany. Pojęcia te przybliża Barbara Rozwadowska następująco: „Wizerunek zwykły odzwierciedla powszechnie istniejące, a zatem potoczne opinie na temat danej organizacji. Wizerunek lustrzany mówi o tym, jak instytucja ocenia samą siebie, przy czym najczęściej chodzi tu o opinię zarządu. Kwestię tę można jednak potraktować szerzej i oceny wizerunku firmy mogą dokonywać wszyscy jej pracownicy. (...) Wizerunek pożądany, czyli taki, jaki organizacja chciałaby posiadać. Najczęściej jest on tworzony na podstawie misji organizacji. Pożądany wizerunek może wydawać się czasem bardzo idealistyczny i z tego powodu trudny do zrealizowania, nie oznacza to jednak, że firma powinna z niego rezygnować. Wizerunek pożądany powinien być traktowany jako pewien cel, do którego przedsiębiorstwo winno dążyć w długim okresie (nawet 10-15 lat)"19.

Budowanie wizerunku jest procesem niezwykle pracochłonnym i czasochłonnym, odbywa się na wielu płaszczyznach, a jego ostateczny kształt określają subiektywne opinie. Ocena wizerunku biblioteki, podobnie jak innych instytucji, jest trudna, bowiem polega na mierzeniu tego, co wydaje się niemierzalne i podlega wielopłaszczyznowym wpływom. Jeden z badaczy tego zjawiska proponował wykorzystanie macierzy celów wizerunkowych w procesie oceny efektów public relations ${ }^{20}$. W bibliotekach, o ile dobrze wiadomo autorowi artykułu, nie testowano do tej pory tego typu narzędzi. Sugerując się

\footnotetext{
${ }^{18}$ J. Szocki, Wizerunek firmy w mediach, Poznań 2008, s. 34.

${ }^{19}$ B. Rozwadowska, op. cit., s. 56.

${ }^{20} \mathrm{D}$. Tworzydło, Macierz celów wizerunkowych $w$ procesie oceny efektów public relations, Rzeszów 2008, s. 40.
} 
badaniami w innych obszarach i dokonując twórczej ekstrapolacji wyników na rzeczywistość biblioteczną, autor proponuje wyznaczyć kilka obszarów, które wpływają na wewnętrzny wizerunek biblioteki. Są to:

- $\quad$ szeroko rozumiane zarządzanie procesami komunikacji i wymiany informacji;

- $\quad$ relacje wewnętrzne, poziom motywacji pracowników;

- $\quad$ wizerunek kierownictwa, styl i system zarządzania;

- $\quad$ atmosfera w miejscu pracy;

- $\quad$ warunki rozwoju pracowników;

- działania integracyjne;

- $\quad$ komunikacja interpersonalna;

- $\quad$ warunki pracy;

- $\quad$ system identyfikacji pracowników;

- dobry wizerunek zewnętrzny.

Wśród determinantów wizerunku zewnętrznego hierarchicznie najważniejszą rolę powinny odgrywać:

- $\quad$ standardy komunikacji i relacje z użytkownikami biblioteki;

- $\quad$ wypracowana marka książnicy;

- jakość oferty analogowej i elektronicznej oraz usług w tym zakresie;

- $\quad$ procesy komunikacji z otoczeniem i relacje z mediami;

- $\quad$ wiarygodność i uczciwość;

- zaangażowanie społeczne;

- tożsamość biblioteki (historyczna i kulturowa, w tym historia książnicy - jeśli to możliwe, opisana);

- $\quad$ programy i działania public relations;

- $\quad$ działania pracowników jako ambasadorów biblioteki;

- $\quad$ pozycja na rynku (wśród innych książnic w mieście, regionie, kraju) i wyniki rankingowe;

- działania reklamowe, techniczne środki oddziaływania;

- imprezy kulturalne skierowane do otoczenia;

- $\quad$ biblioteka jako miejsce;

- $\quad$ zaangażowanie w sponsoring, współpracę regionalną i udzielanie poparcia instytucjonalnego (markowego) dla określonych działań w miejscu lub $\mathrm{kraju}^{21}$.

Wizerunek jest intelektualną lub zmysłową interpretacją instytucji, przedmiotu lub osoby, uwarunkowaną dodatkowo przez cechy podmiotu (emocje, postawy, wartości), w którego umyśle powstaje określony wizerunek ${ }^{22}$. Wizerunek można więc określić jako subiektywne postrzeganie instytucji/biblioteki przez jej otoczenie. Wizerunek nie jest wierną kopią wyobrażonego przedmiotu $\mathrm{z}$ uwagi na aktywność i subiektywność procesu spostrzegania. Istotna z punktu widzenia działalności różnego typu instytucji bibliotecznych jest możliwość

\footnotetext{
${ }^{21}$ Ibidem.

${ }^{22}$ A. Davis, Public Relations, Warszawa 2007, s. 47-48.
} 
kształtowania wizerunku, rozumiana jako nadawanie mu wśród odbiorców określonego kształtu psychologicznego ${ }^{23}$. Biblioteki, niezależnie od ich typów i miejsca $\mathrm{w}$ środowisku, nie prowadzą polityki wizerunkowej, jednak dzielą ze sobą wspólny wizerunek. Na podstawie przypadkowych zazwyczaj doświadczeń z kilku instytucji, powstają opinie na temat biblioteki w ogólności. Często bywa tak, że wyobrażenie biblioteki jest nieaktualne, bowiem dotyczy relacji z odległej przeszłości lub ma charakter lokalny, gdyż wynika z dobrych lub złych kontaktów interpersonalnych w określonym miejscu, gdzie biblioteka funkcjonuje.

Reasumując, należy stwierdzić, że między wizerunkiem a tożsamością biblioteki występują dość subtelne, ale istotne różnice. Na pojęcie tożsamości instytucji składają się poczucie odrębności od otoczenia, poczucie ciągłości własnego ja (stałość w czasie, pomimo zmian, jakie zaszły), poczucie wewnętrznej spójności oraz poczucie posiadania wewnętrznej treści ${ }^{24}$. Naturalnie, instytucja jako taka nie ma zdolności dosłownego odczuwania, ale w tym wypadku chodzi o punkt widzenia otoczenia zewnętrznego i wewnętrznego (sądy pracowników instytucji). Wyrazistą tożsamość biblioteki tworzą wszystkie elementy, za pomocą których jest identyfikowana i które powodują, że nie jest mylona z innymi instytucjami. Według opinii badaczy tożsamość organizacji (corporate identity) określają czynniki zawarte we wzorze: $\mathrm{CI}=\mathrm{CB}+\mathrm{CC}$ $+\mathrm{CD}^{25}$.

CB (corporate behaviour) to normy zachowań obowiązujące w organizacji, CC (corporate communications) stanowią sposoby komunikowania się organizacji z otoczeniem, natomiast CD (corporate design) oznacza tożsamość wizualną organizacji. Na podstawie powyższego wzoru można wyciągać wnioski odnośnie aktualnej i przyszłej tożsamości bibliotek w zmieniającym się otoczeniu gospodarczym, społecznym i kulturowym.

\section{Misja zawodu bibliotekarskiego i biblioteki jako instytucji}

Misja zawodu określa szczegółowe cele jakie ma spełniać profesja w zaspokajaniu potrzeb społecznych. Misja zawodu bibliotekarskiego wyznacza kierunek i jest nastawiona na przyszłość, wyraża oczekiwania i wyzwania, które stają się udziałem pracowników tej grupy zawodowej, a także to, czy proces jej realizacji jest wiarygodny. Kultura biblioteki narzuca jej określony sposób działania i określa stopień suwerenności. Jej skuteczność wyznaczają innowacje, elastyczność, jakość usług i opanowana sztuka wprowadzania zmian, podobnie jak w przypadku planowania strategicznego w nowoczesnej firmie ${ }^{26}$.

\footnotetext{
${ }^{23}$ Por. W. Budzyński, Wizerunek równolegty. Nowa szansa promocji firmy i marki, Warszawa 2008, s. 11.

${ }^{24}$ Por. A. Gałdowa, Tożsamość człowieka, Kraków 2000, s. 47.

${ }^{25}$ J. Filipek, Tożsamość wizualna firm, ,, Marketing i Rynek” 1995, nr 9, s. 11.

${ }^{26}$ Por. Strategor, Zarządzanie firma, Warszawa 1997, s. 294-295.
} 
Kultura organizacyjna bibliotek, czerpiąca współcześnie z historii tej instytucji, określa stopień doskonałości i sprawności w opanowaniu rzemiosła bibliotekarskiego, jego szczególnych umiejętności i specjalności. Stanowi ona swoisty drogowskaz prowadzący do samoczynnego rozwoju oraz przezwyciężenia kryzysów. W literaturze z zakresu zarządzania można znaleźć różnorodne określenia kultury organizacji, ale należy podkreślić, iż pojęcie to ma doskonałe walory adaptacyjne na gruncie bibliotekoznawstwa. Dość łatwo bowiem dostrzec, że biblioteczna kultura organizacji jest wytworem historii utrwalonym tradycją i przekazywanym z pokolenia na pokolenie; stanowi niepisany kodeks wartości, wzorców zachowań organizacyjnych, symboli, postaw i orientacji pracowników bibliotek. Kultura organizacyjna bibliotek wykazuje również liczne wpływy środowiska kulturowego i polskiej walki o byt narodowy ${ }^{27}$. Te wszystkie elementy tworzą system znaków, który umożliwia określoną interpretację rzeczywistości i nadawanie realnego kształtu organizacji ${ }^{28}$. Liczne artefakty kultury narodowej, jak Scriptorum Polonicorum Hekatontas Szymona Staropolskiego, Bibliografia Polska Estreicherów czy Biblioteka Rzeczypospolitej braci Załuskich budują naturę rzeczywistości, w której doskonale odnajdują się bibliotekarze i kolejne pokolenia Polaków.

W literaturze bibliotekoznawczej niewiele miejsca poświęca się planowaniu strategicznemu współczesnych bibliotek, a wszystko wskazuje na to, iż jest ono niezbędnym elementem wypełniania misji tych instytucji. Planowanie strategiczne to proces ustalania długoterminowych celów, dokonywania systematycznych analiz otoczenia i potencjału instytucji oraz podejmowania decyzji, co do przyporządkowania środków (budżetowych, produkcyjnych, materiałowych) i sposobów realizacji ${ }^{29}$. Spośród znanych zarządczych koncepcji planowania strategicznego, najczęściej wymienia się szkoły: planistyczną, ewolucyjną, pozycyjną i zasobową. W odniesieniu do instytucji bibliotecznej prawdopodobnie najlepiej sprawdza się połączenie koncepcji szkoły pozycyjnej i zasobów. Fundamentalnym założeniem pierwszej z nich było osiąganie przewagi konkurencyjnej i wykorzystanie badań operacyjnych dla stworzenia zbioru technik optymalizacyjnych, użytecznych w różnych obszarach działania organizacji. Podejście pozycyjne ma charakter normatywny i dydaktyczny, a za punkt wyjścia przyjmuje analizę otoczenia instytucji, która decyduje o skuteczności organizacji i jej sukcesie; podstawową strategią tego podejścia jest

${ }^{27}$ Autor ma tu na myśli organizacje społeczne i towarzystwa czytelnicze działające na przełomie XIX i XX wieku, między innymi Wydział Czytelń Warszawskiego Towarzystwa Dobroczynności, Towarzystwo Czytelni Ludowych, Towarzystwo Szkoły Ludowej, Polska Macierz Szkolna.

${ }^{28}$ Por. E. Gujańczyk, Kultura organizacyjna jako element kreowania organizacji przedsiębiorczej, [w:] Przedsiębiorczość w zarzadzaniu i socjologii, red. E. Mieszajikina, R. Maciejewska, Lublin 2012, s. 33-42; K. Bolesta-Kukułka, Decyzje menedżerskie, Warszawa 2003, s. 103; M. Kostera; Zarządzanie międzykulturowe, [w:] Zarządzanie, red. A.K. Koźmiński, W. Piotrowski, Warszawa 2004, s. 439.

${ }^{29}$ Por. I. Penc-Pietrzak, Planowanie strategiczne w nowoczesnej firmie, Warszawa 2010, s. 14. 
minimalizacja kosztów i zróżnicowanie produktów ${ }^{30}$. Druga ze szkół - zasobowa - przyjęła jako główną przesłankę działania i źródło sukcesów zrozumienie konfiguracji unikalnych zasobów i umiejętności, które dają firmie kluczowe kompetencje. Szkoła zasobowa poszukiwała odpowiedzi na pytanie, co powoduje, że określone zasoby i umiejętności są cenne. Instytucja działająca według tej filozofii, dynamicznie dopasowuje swoje zamierzenia do zasobów i wykorzystuje je, budując unikalne konfiguracje na danym rynku ${ }^{31}$.

Najważniejszym elementem planowania strategicznego są ludzie. Wśród stereotypowych cech bibliotekarzy, wymienia się: kryształową uczciwość, pracowitość, umiłowanie porządku, komunikatywność i chęć służenia pomocą. To świetny kapitał na przyszłość. Jaki typ pracy w bibliotece jest potrzebny współcześnie? Wśród współczesnych bibliotekarzy zauważalne są trzy typy pracy, które często, ale nie zawsze, wiążą się z typem przygotowania, wiekiem i stylem wcześniejszej pracy. Na czoło wybija się bibliotekarz jako adaptator:

1. Typ adaptacyjny (tradycyjny) - to bibliotekarz, który reprezentuje nastawienie zachowawcze, jego cechy są wręcz stereotypowe: precyzyjny, zdyscyplinowany, godny zaufania, akceptuje przedstawione założenia problemu, można na nim polegać, potrafi dobrze zaplanować i zorganizować czas. Bibliotekarz-adaptator koncentruje się na rozwijaniu istniejących struktur, dążąc do ulepszenia działania biblioteki.

2. Typ innowacyjny. Bibliotekarz-innowator postrzegany jest jako trudny do kierowania niezdyscyplinowany. Posiada wyobraźnię, tworzy własne wizje, często kwestionuje cele i decyzje przełożonych. Innowatorzy są zwolennikami daleko idących zmian, niekiedy tylko po to, żeby zobaczyć, co się stanie. Stwarzają więc niepotrzebne ryzyko, są mniej efektywni w działaniach, mają skłonności do podejmowania wielu zadań jednocześnie, są niezorganizowani.

3. Typ umiarkowany - to bibliotekarz, który dąży do osiągnięcia średniej wyników. Bibliotekarz-umiarkowany może występować w dwóch rolach/ kategoriach: jako umiarkowany adaptator przejawiający preferencje zbliżone do stylu adaptacyjnego oraz jako umiarkowany innowator przejawiający preferencje zbliżone do stylu innowacyjnego.

Obydwie kategorie mieszane pełnią rolę po mostu pomiędzy kategoriami skrajnymi: innowatorami i adaptatorami. W bibliotekach mogą oni być bardzo przydatni, bowiem w naturalny sposób potrafią dostrzegać różne punkty widzenia, działać jako pośrednicy w komunikacji pomiędzy skrajnymi grupami, grać role mediatorów w rozwiązywaniu konfliktów ${ }^{32}$.

${ }^{30}$ Por. ibidem, s. $17-18$.

${ }^{31}$ Por. ibidem.

${ }^{32}$ Autor opracowując powyższą typologię opierał się na: R. Muszkieta, Ocenianie osiągnięć uczniów przez nauczycieli wychowania fizycznego, Poznań 2004; N. Beer, N. Nohria, Kombinacja twardej i łagodnej filozofii zmian, „Zarządzanie na Świecie” 2000, nr 7, s. 11-17; M. Bratnicki, Zarzadzanie zmianami w przedsiębiorstwie, Katowice 1998; D. K. Carr, K.J. Hard, W.J., Trahan, Zarządzanie procesem zmian, Warszawa 1998; L. Clarke, Zarzqdzanie zmiana, Warszawa.1997; R.W. Griffin, Podstawy zarządzania organizacjami, Warszawa 
Jakie powinny być ogólne kompetencje współczesnych bibliotekarzy? Są to przede wszystkim:

1. Wychowawcze i społeczne - związane z umiejętnością rozpoznawania potrzeb użytkowników oraz zdolnością do współpracy w relacjach międzyludzkich.

2. Informacyjno-medialne - wyrażające się umiejętnością posługiwania się technologią informacyjną, $w$ tym jej wykorzystywaniem w codziennej pracy merytorycznej i prowadzeniu zajęć praktycznych.

3. Kreatywne - wyrażające się zdolnością do samokształcenia, innowacyjnością i niestandardowością działań w powiązaniu ze zdolnościami adaptacyjnymi, mobilnością i elastycznością.

4. Językowe - wyrażające się skutecznością komunikacyjną (werbalną i pozawerbalną), wysoką komunikatywnością w języku rodzimym i znajomością języka obcego w stopniu zaawansowanym;

5. Prakseologiczne - wyrażające się skutecznością w planowaniu, realizacji, organizowaniu, kontroli i ocenie procesów biblioteczno-informacyjnych.

Hierarchia tych kompetencji i ich interpretacja jest sprawą do dyskusji; powinna być dobierana przez pion zarządzający biblioteki w zależności od typu placówki i jej potrzeb.

Dynamika zmian w obrębie zawodu bibliotekarskiego pokazuje konieczność definiowania tej profesji poprzez wyzwania współczesności. Innowacje w pracy bibliotekarzy wynikają z przemian technologicznych w samych bibliotekach, ale też w ich bezpośrednim otoczeniu. Misja współczesnych bibliotek powinna być realizowana poprzez dbałość środowiska bibliotekarskiego o tożsamość instytucji i jej najlepszy wizerunek - to najskuteczniejsze antidotum na deregulację zawodu i inne zagrożenia cywilizacyjne i administracyjne. Ocena pracy biblioteki to osiągane rezultaty statystyczne, ale przede wszystkim potoczne sądy członków społeczności o przydatności tej instytucji dla środowiska. Elementem kreowania wizerunku bibliotek na zewnątrz powinna być ich otwartość na wszystkich płaszczyznach (w tym również łatwo dostrzegalna otwartość bibliotekarzy na zmiany i akceptacja trudnej czasami rzeczywistości). Misją bibliotekarza jest także przeobrażenie środowiska jego własnymi siłami, tworzenie szerokich interakcji społecznych, rewitalizacji kultury ${ }^{33}$. Zewnętrzna misja biblioteki to podtrzymywanie różnorodnych więzi społecznych i ich animowanie; biblioteka staje się miejscem spotkań i aktywności kulturalnej całego środowiska, którego potrzeby zaspokaja. Charakterystyczne stało się

1999; M. Kuleta, Czlowiek jako kreator zmian w swoim życiu, [w:] Człowiek wobec zmiany: rozważania psychologiczne, red. D. Kubacka-Jasiecka, Kraków 2002; Z. Mikołajczyk, Zarzadzanie procesem zmian $w$ organizacjach, Katowice 2003; S.P. Robbins, Zasady zachowania w organizacji, Poznań 2001.

${ }^{33} \mathrm{O}$ idei przeobrażania środowiska jego własnymi siłami pisała już Helena Radlińska. Zob.: W. Theiss, Heleny Radlińskiej koncepcja badania i działania, [w:] Helena Radlińska. Człowiek $i$ wychowawca, red. I. Lepalczyk, B. Wasilewska, Warszawa 1994/95, s. 17-32. 
przenikanie zakresów działalności różnych typów bibliotek, widoczne w działalności społecznej, zarówno książnic publicznych, jak i naukowych. Propagowanie uczestnictwa kulturowego przez biblioteki daje bibliotekarzom szanse wyrobienia w społeczności przekonania, iż posiada ono własną ekspresję kulturową, samoświadomość i tożsamość, a to z kolei przeciwdziała alienacji jednostek w chaosie popkultury; jest to także szansa na powrót do kultury ludzi odciętych od korzeni w konsumpcyjnym świecie.

\section{Bibliografia}

Beer N., Noria N., Kombinacja twardej i łagodnej filozofii zmian, „Zarządzanie na Świecie” $2000, \mathrm{nr} 7$.

Bolesta-Kukułka K., Decyzje menedżerskie, Warszawa 2003.

Bratnicki M., Zarządzanie zmianami w przedsiębiorstwie, Katowice 1998.

Budzyński W., Wizerunek równoległy. Nowa szansa promocji firmy i marki, Warszawa 2008.

Budzyński W., Zarzadzanie wizerunkiem firmy, [w:] Metody badania wizerunku $w$ mediach, red. T. Gackowski, M. Łączyński, Warszawa 2009.

Carr D.K., Hard K.J., Trahan W.J., Zarzadzanie procesem zmian, Warszawa 1998.

Clarke L., Zarzadzanie zmianq, Warszawa.1997.

Cott J., Myśl to forma odczuwania, Susan Sontag w rozmowie z..., Kraków 2014.

Davis A., Public Relations, Warszawa 2007.

Dunin-Borkowski S., O obowiazkach bibliotekarza, Lwów 1829.

Epstein J., Rewolucyjna przyszlość książek, [w:] Ekonomia kultury. Przewodnik Krytyki Politycznej, Warszawa 2010.

Filipek J., Tożsamość wizualna firm, „Marketing i Rynek” 1995, nr 9, s. 11.

Gałdowa A., Tożsamość człowieka, Kraków 2000.

Griffin R.W., Podstawy zarządzania organizacjami, Warszawa 1999.

Gujańczyk E., Kultura organizacyjna jako element kreowania organizacji przedsiębiorczej, [w:] Przedsiębiorczość w zarzadzaniu i socjologii, red. E. Mieszajikina, R. Maciejewska, Lublin 2012, s. 33-42,

Kostera M., Zarządzanie międzykulturowe, [w:] Zarządzanie, red. A.K. Koźmiński, W. Piotrowski, Warszawa 2004.

Kuleta M., Człowiek jako kreator zmian w swoim życiu, [w:] Człowiek wobec zmiany: rozważania psychologiczne, red. D. Kubacka-Jasiecka, Kraków 2002.

Ladorucki J., Małe ojczyzny - lokalne biblioteki - nowe oblicza bibliotekarskiej profesji, [w:] Bibliologia i informatologia, red. D. Kuźmina. Warszawa 2011, s. 89-99.

Levinson P., Miękkie ostrze, czyli historia i przyszłość rewolucji informacyjnej, Warszawa 2006.

Mikołajczyk Z., Zarzadzanie procesem zmian w organizacjach, Katowice 2003.

Muszkieta R., Ocenianie osiagnięć uczniów przez nauczycieli wychowania fizycznego, Poznań 2004.

Ostrowski Ł., Wizerunek bibliotek publicznych. Raport z badań, [dostęp: 01.06.2015], https:// wirtualnysegregator.org/repository/PLIKI/DOKUMENTY/RAPORTY/03_wizerunek_bib liotek_publicznych_raport_PRB.pdf.

Peiper T., Ma lat 22, Kraków1936.

Penc-Pietrzak I., Planowanie strategiczne w nowoczesnej firmie, Warszawa 2010.

Pomian K., Przeszłość jako przedmiot wiedzy, Warszawa 2010.

Robbins S.P., Zasady zachowania w organizacji, Poznań 2001. 


\section{2}

Rozwadowska B., PR. Teoria. Praktyka. Perspektywy, Warszawa 2009.

Strategor, Zarzadzanie firma, Warszawa 1997.

Szocki J., Wizerunek firmy w mediach, Poznań 2008.

Theiss W., Heleny Radlińskiej koncepcja badania i działania, [w:] Helena Radlińska. Człowiek $i$ wychowawca, red. I. Lepalczyk, B. Wasilewska. Warszawa 1994/95.

Tworzydło D., Macierz celów wizerunkowych w procesie oceny efektów public relations, Rzeszów 2008. 